\title{
Mana e substâncias xamânicas: as reconfigurações de poder entre os Siona da Colômbia ${ }^{1}$
}

\author{
ESTHER JEAN LANGDON
}

Meu trabalho é inspirado pelo recém publicado dossiê da Revista Social Compass (Crépeau e Laugrand 2017). dedicado a repensar as noções de "tipo mana" por meio de etnografias de povos específicos. Os organizadores sugerem que tais noções são amplamente encontradas nas cosmologias indígenas e que são expressadas como substâncias, fluidos, forças, poder ou potência, que circulam entre os seres humanos e não humanos. Eles sugerem também que a exploração dessas ideias tipo mana expressadas nas práticas sociais contribuiria para aprofundar o entendimento da dinâmica nas relações entre humanos e não humanos, permitindo-nos superar a tensão entre estrutura e prática inerente às discussões da virada ontológica (Costa e Fausto 2010:95; Crépeau e Laugrand 2017). Com o objetivo de aprofundar a noção de força xamânica como exemplo de um tipo mana nas práticas dos Siona da Colômbia, examino especificamente sua noção de rau, um termo polissêmico que se aproxima da noção de mana em seus significados e usos.

O conceito de mana foi primeiramente registrado pelos missionários entre os povos da Oceania e encontrado em suas traduções da Bíblia para as línguas nativas no século XIX como parte de suas tentativas para traduzir as noções de sobrenatural dos "primitivos”. Em 1878, Max Müller, citando a carta do missionário-antropólogo Codrington, apresentou o conceito de mana que se tornaria a base da definição clássica: Os povos da Oceania “... tem a crença numa força totalmente distinta do poder fisico, que age de várias maneiras para o bem e o mal, e que possui-la ou controla-la é de vantagem maior. Isto é o mana" (Tomlinson e Tengan 2016: 3). Mana se tornou foco do interesse nos finais do século XIX, particularmente na região da Oceania. Noções semelhantes foram identificadas em outras partes do mundo, tais como orenda entre os Iroqueses, manitu entre Algonquianos ou nabual entre os povos de México.

1 Traduzido do inglês por Nádia Heusi Silveira. 
Em 1902, Marcel Mauss, com a colaboração de Henri Hubert (1974), resumiu os exemplos etnográficos de mana no seu Esboço sobre uma Teoria Geral da Magia. Argumentaram pela universalidade dessa noção e identificaram como tipo mana os termos análogos para expressar essa força, tais como orenda, manitu e nahual. Mana e as ideias tipo mana não tratam de uma ilusão, simbolizam a noção de "força-meio mágica" e representam o poder místico do coletivo ou social. Embora seja difícil de definir ou precisar, Mauss e Hubert caracterizam o mana como: (1) uma qualidade que as coisas possuem; (2) uma substância ou essência manejável, mas independente; e, (3) uma força dos seres espirituais, das almas e dos xamãs (ou dos mágicos, na linguagem de Mauss) (Mauss 1974: 138-139). Para eles, o mana é uma categoria do pensamento mais geral que a do sagrado, sendo a força que se expressa tanto na religião quanto na magia. ${ }^{2}$

Recentemente, Tomlinson e Tengan (2016) organizaram um volume dedicado ao tema, retomando a discussão sobre mana não tanto por sua importância nas teorias antropológicas, mas tendo em vista os novos discursos e seus usos fora da academia, nos campos políticos, religiosos e artísticos. Mana hoje possui novos significados e faz parte das representações e discursos dos movimentos étnicos de vários povos que vivem na Nova Zelândia, na Austrália, no Havaí e em outros locais da Oceania. Os objetos ancestrais contendo mana que se encontram em museus têm sido alvo de processos e reivindicações de repatriação por parte de grupos étnicos. O mana está vivo nas religiões evangélicas, está presente nas roupas, bebidas e estilos de vida. Revistas de arte e de antropologia adotaram mana como título e o tema tem sido a inspiração para novelas e poemas. Um exemplo é o livro que se tornou filme, Uma Vez Fomos Guerreiros, o qual retrata a violência e desintegração social entre os Maori urbanos da Nova Zelândia. (foto1: Cartaz do Filme Uma Vez fomos Guerreiros) Em contextos globais, as religiões da Nova Era, os jogos de computador e a literatura de ficção científica/fantástica têm se apropriado do conceito como um objeto, independentemente de seu lugar de origem ou de sua identidade étnica, política ou religiosa, a ser aproveitado de novas maneiras (Tomlinson e Tengen 2016: 13).

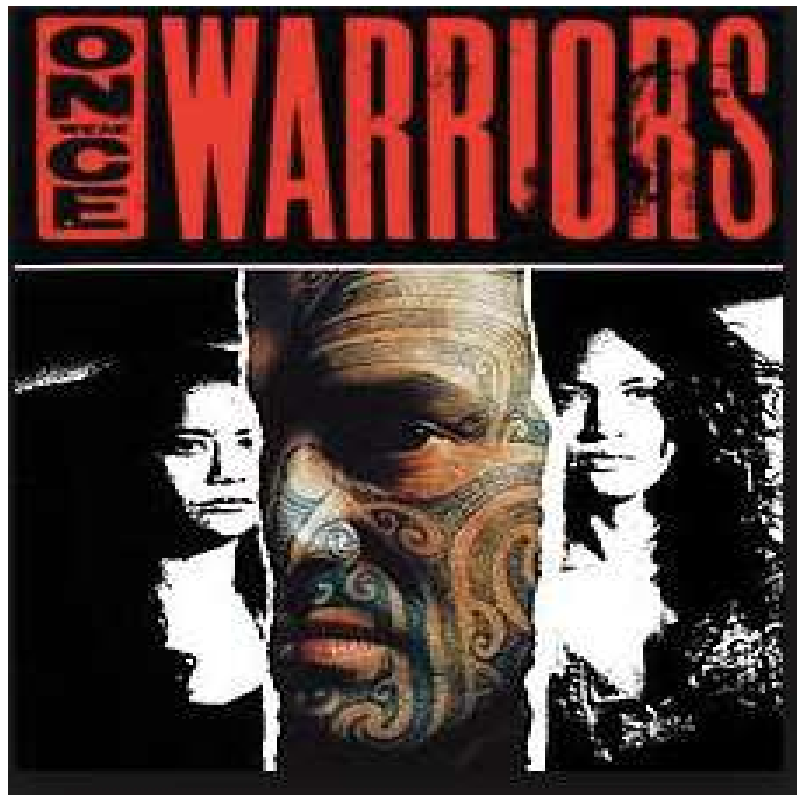

Foto 1: Cartaz do Filme Uma Vez fomos Guerreiros

2 Lévi-Strauss, em 1950, na introdução da obra Sociologia e Antropologia, de Mauss, identificou as noções de tipo mana como uma forma universal do pensamento (Lévi-Strauss 1974: 34). Porém, ele reduziu o conceito a um valor formal semântico, como uma categoria de pensamento, e o separou dos contextos culturais específicos e das práticas sociais. 
Historicamente, na etnologia das terras baixas da América do Sul, pouca atenção foi dada a esse conceito e, hoje, a discussão é eclipsada pelas elaborações relativas a animismo e predação, com seu enfoque pós-estruturalista sobre a relação entre os seres humanos e não humanos (Crepeau, Laugrand 2017: 313). Desde a década de 1990, as discussões dos conceitos de animismo e perspectivismo vêm orientando as análises antropológicas sobre os xamanismos amazônicos (Costa e Fausto, 2010), com a premissa de que há, entre todos os seres, uma continuidade de almas, mas não de corpos. Segundo o perspectivismo, o problema central nas negociações com os não humanos trata de tomar a perspectiva do outro. Num esforço para avançar o entendimento sobre xamanismo, quero ampliar a discussão tomando como ponto de partida a noção de mana, conceito tão clássico quanto animismo, mas pouco examinado, atualmente, nas análises etnográficas sobre os povos amazônicos e seus mundos ontológicos.

\section{Substâncias xamânicas}

Num artigo de 2007, Robert Crepeau explora e compara a polissemia das substâncias xamânicas nas práticas rituais de vários grupos amazônicos, em que sugere que devem ser consideradas como expressões de tipo mana. Ele afirma que a análise de substâncias xamânicas, a partir das práticas indígenas, será frutífera para aprofundar nosso entendimento sobre a relação entre os xamãs e os seres não humanos (Crepeau 2007:120). Segundo ele, as noções e práticas que envolvem o uso de substâncias xamânicas são centrais para entender a fonte de forças místicas por trás das mediações e trocas presentes nas ontologias ameríndias, bem como nas relações entre o xamã e seus aliados não humanos.

Aqui examino a noção de rau como um aspecto central para entender a cosmologia xamânica e as práticas rituais entre os Siona da Colômbia. Portanto, em vez de tratar rau como uma categoria estável no pensamento indígena, exploro essa noção como um conceito fluido e polissêmico que tem sofrido transformações em decorrência das mudanças nas práticas xamânicas frente a processos históricos e sociais. Como as discussões recentes sobre o mana demonstram, rau é melhor entendido como um fenômeno social cujo uso e significado tem se transfigurado através do tempo e espaço (Kolshus, 2013). Examinarei o significado dessa noção e suas implicações para o xamanismo siona durante três períodos: no período colonial, quando o termo é encontrado em vocabulários compilados pelos missionários; no século XX, momento em que as práticas xamânicas entraram em declínio; e, no século XXI, quando observamos uma revitalização vigorosa das práticas xamânicas. Minha análise baseia-se em documentos históricos e contemporâneos, como também em meus diários de campo e transcrições de inúmeras narrativas xamânicas registradas na década de 1970. Desde os anos 1980 tenho retornado ao Putumayo, em várias viagens, de maneira que estou acompanhando seus ritos e práticas por quase meio século.

\section{A noção de rau em 1970}

Ainda lembro a primeira vez que a noção de rau chamou minha atenção, em 1971. Estava revisando a transcrição de uma narrativa contada por Ricardo Yaiguaje, um grande narrador que gostava 
de lembrar das batalhas xamânicas na história dos Siona. Ricardo estava narrando uma batalha entre dois xamãs, um dos quais vestia a roupa da sucuri. De acordo com a narrativa, o xamã retirava uma substância do seu corpo e, juntando-a, formava um projétil que atirava na sucuri. No texto em siona, Ricardo usou o termo rau para se referir à substância que era trocada entre os xamãs. Até esse momento, minha definição de rau era "doença" e eu estava perplexa com o novo uso do termo rau. Ricardo tinha dificuldades em traduzir o conceito e sugeriu "bruxo". Explicou que é uma substância existente dentro dos xamãs e que eles podem retirar para formar projéteis, seja na forma de flecha ou de pedra apontada, que atiram em sua vítima com a finalidade de causar doença.

Os Siona, encontrados ao longo do rio Putumayo, na fronteira entre Colômbia, Equador e Peru, compartilham, de modo geral, os princípios epistemológicos e ontológicos que têm sido descritos para outros grupos amazônicos (Seeger, DaMatta e Viveiros de Castro 1987; Viveiros de Castro, 1998; 2006). O mundo cosmológico existe em constante transformação. É um mundo em que distinções tais como natureza/cultura, animal/humano ou natural/sobrenatural não são aplicáveis. $O$ universo é constituído por vários níveis habitados por uma multiplicidade de donos/mestres e suas coletividades. A natureza transformativa do cosmos e a mudança de perspectiva que determina as aparências são expressadas pelos Siona pelo conceito de can'co ou "lado". Percepção e experiência têm lados diferentes: $\ddot{e}$ can'co, ou “este lado", designa o que normalmente é visível, enquanto o “outro lado", yequë can'co, é onde existem as forças ocultas que influenciam e interferem nos processos coletivos de bem-estar. Porém a percepção correta do outro lado depende da consciência de si e do conhecimento xamânico, a fim de poder enxergar o que é "real" no lado que é normalmente invisível.

A pessoa entra no outro lado por meio dos rituais com a ingestão de yajé (Banisteriopsis sp.) ou pelos sonhos. ${ }^{3}$ Por conta dos conhecimentos adquiridos durante sua aprendizagem com yajé, os xamãs têm a capacidade de perceber mais claramente o outro lado e de negociar com os seres invisíveis para proteger e defender seu grupo ou para atacar outros. Até a década de 1960, esperava-se, entre os Siona, que todos os homens realizassem a aprendizagem xamânica no processo de tornar-se adulto. Desse modo, alguns homens, dependendo nas suas capacidades, podiam mediar as relações com os seres do outro lado, discernir corretamente a natureza verdadeira e as causas dos eventos nesse lado, influenciar os donos dos seres não humanos para assegurar o bem-estar de suas famílias, ou ainda, defender-se contra ataques invisíveis (Langdon 2014).

O xamã, frequentemente chamado pelo título quéchua de curaca, era uma pessoa reconhecida por possuir rau suficiente para lidar com a comunidade nos seus ritos de yajé. Na língua siona, ele foi designado por uma variedade de palavras, indicando suas capacidades por possuir rau: yai - onça; uncuguë - bebedor de yajé ou ënaguë - vidente. Todas essas designações referenciam suas capacidades de transformação, de percepção da natureza verdadeira dos eventos, de adivinhar o futuro ou ver os eventos no passado, bem como de liderar o grupo nos ritos que levam a viagens para o outro lado. O poder de cura era somente uma parte dos atributos do curaca. A possessão de rau lhe dotava com a agência para fazer o mal ou o bem, dependendo da sua intenção.

3 É possível ter um encontro acidental com seres do outro lado ou até perder-se no outro lado quando sozinho na floresta. Tais encontros são fontes de perigo e, para se salvar, é necessário perceber corretamente. 
Análoga ao conceito mana de várias maneiras, a noção de rau representa a fonte de poder místico e seu significado se encontra num campo semântico amplo, abrangendo a existência, a vida e a morte. Os processos da vida são concebidos como cíclicos, do mesmo modo que o ciclo das estações, das constelações no céu, bem como as fases crescentes e minguantes da lua. Rau teve um papel central no xamanismo e na mediação entre humanos e não humanos, que influencia os processos envolvidos nesses ciclos, as alterações entre saúde e doença, a vida e a morte. Sua importância nas práticas rituais tem sido observada desde o período colonial. Nos anos 1970, quando os xamãs siona não estavam realizando os rituais para o bem-estar da comunidade, a noção ainda estava presente nas interpretações sobre as doenças e narrativas que contaram. No final da década de 1980, as práticas rituais foram retomadas, em parte estimuladas pelo movimento indígena na luta para o reconhecimento da cidadania e, em parte, pela demanda de profissionais urbanos por rituais de yajé conduzidos por xamãs amazônicos. Paradoxalmente, a importância e os significados multivocais do conceito rau estão diminuindo com a revitalização de rituais xâmanicos no século XXI.

Hoje, os xamãs, conhecidos como taitas, são figuras públicas reconhecidas como autoridades pelas comunidades siona e pela Constituição Nacional de 1991. São também reconhecidos como sábios e taitas pelos grupos espirituais da Nova Era que participam nas suas tomas de yajé (Caicedo-Fernandez 2015). Aproveitando as recentes discussão sobre mana, exploro as continuidades e rupturas das traduções de rau como agência e substância xamanica em três períodos históricos.

\section{A época colonial: rau como bruxo}

Antes da chegada dos espanhóis, os povos da língua tucano-ocidental, que inclui hoje os Siona, Secoya, Acutero, Mai Bai e remanescentes de outros grupos, ocuparam um território amplo nas bacias dos rios Putumayo, Aguarico e Napo, na Colômbia, Equador e Peru. (Mapa Territorio dos Siona na Epoca Colonial) Viviam dispersados em toda a região em grupos pequenos, de 30 a 70 pessoas. As forças espanholas entraram a região do Putumayo, no século XVI, com o objetivo de minerar os depósitos aluviais de ouro. Mais tarde, missionários jesuítas e franciscanos tentaram congregar os indígenas em centros permanentes, visando à exploração de sua mão de obra e conversão religiosa. Os Tucano ocidentais foram particularmente resistentes à evangelização e ao deslocamento forçado para as missões (Langdon, 2014; Cipolletti, 1999; 2011). As missões duraram pouco e vários padres foram assassinados. $\mathrm{O}$ isolamento, junto às epidemias e à resistência indígena, resultaram no fim da maior parte das atividades missionárias, na região do rio Putumayo, no final do século XVIII (Gómez López, 2006).

Um vocabulário extensivo da língua secoya, compilado em 1753 por um jesuíta anônimo, indica que era atribuído a alguns xamãs, que conduziam seus seguidores em rituais que duravam a noite toda, cantando, dançando e bebendo datura ou yajé, um papel parecido ao de um padre católico (vinia pain e jujaque). $\mathrm{O}$ autor distinguia esses líderes rituais dos bruxos, chamados raube neque ou raube nehuati, os que fazem ou mandam doença (raube) (Cipolletti, 2011: 466). Vinia pain e jujaque foram termos traduzidos como sacerdote, curandeiro ou cantador, este último em referência ao ofício de orar sobre o yajé. Cipolletti observa que, para os Secoya, o conceito de rau "trata de uma expressão semanticamente 
rica: além da pessoa que envia o mal, rawë refere às flechas pequenas que ele atira para causar algum infortúnio ou doença ao outro" (Cipolletti, 2011: 466).

Um manuscrito anônimo da mesma época, possivelmente de origem franciscana, de um vocabulário siona que se encontra na Biblioteca Nacional de Bogotá, contém traduções similares: raube doença; rabueco - bruxo e, rabueque - bruxo (Ortiz 1942: 172).

\section{O cacique-curaca e rau}

A expulsão dos jesuítas trouxe o fim de suas atividades entre os Tucano ocidentais, no Equador, em 1767, enquanto os franciscanos, no rio Putumayo, saíram no final do século XVIII devido ao isolamento e às dificuldades de manter a continuidade das missões. Quase 100 anos depois, a região do Putumayo alcançou importância economica para a Colômbia devido a atividades extrativistas de quina e caucho, e as atividades missionárias foram reassumidas, desta vez pelos capuchinhos. Eles encontram as comunidades siona organizadas sob a liderança de xamãs, designados como cacique-curacas e que cuidaram da vida espiritual e política de seu grupo por meio de ritos comunais de yajé. O cacique-curaca tinha a responsabilidade de cuidar e defender seu grupo dos ataques de rau enviado pelos curacas de outras comunidades. Tradicionalmente, a maior parte dos homens numa comunidade tinha algum conhecimento xamânico e, por consequência, possuía rau, e o mayor seu rau, o maior sua capacidade de causar dano ou doença.

Os capuchinhos, enviados de Popayán, na Colômbia, receberam autoridade e responsabilidade para controlar a região do Putumayo em "nome da pátria e da Igreja”. Fizeram várias excursões às comunidades indígenas, estabelecendo contato, realizando ritos de batismo e casamento, ao tempo que realocaram alguns grupos que viviam no Equador para o lado da fronteira colombiana (Wasserstrom, 2017). Suas atividades, juntamente às dos extrativistas, causaram uma nova onda de epidemias. Então, em poucas décadas, restaram somente três comunidades no rio Putumayo e a população siona foi reduzida a aproximadamente 300 pessoas, um terço do que era em 1900 (Langdon 2014).

Os capuchinhos conduziram investigações linguísticas e também etnográficas em todo o Putumayo. Compilaram vocabulários e registraram mitos e costumes sobre a vida religiosa dos Siona com o fim de traduzir a doutrina católica nas línguas nativas. Em 1972, localizei vários de seus documentos no Centro de Investigação Linguística e Etnográfica da Amazônia Colombiana, em Bogotá (Langdon 2014: 271-276). Um manuscrito de três páginas escritas à mão, com data de 1945, contém o texto de um canto de Rafael Paiyoguaje, identificado no manuscrito como curaca de Piñuña Blanco (Castellví ms 1944-5). Rafael é lembrado até hoje pelos Siona da comunidade de Buena Vista como o mais malvado dos últimos curacas, responsabilizado por causar doenças e mortes de vários parentes. O texto é traduzido para o espanhol por outro Siona, Lorenzo Piaguaje: 
Como no caso dos manuscritos coloniais, o capuchinho traduz rau como doença e o indígena traduz a frase rau yoocuabi como brujear, em espanhol, ou amaldiçoar. A tradução literal da frase é "trabalhando ou fazendo rau". Deve-se notar que a letra do canto diz respeito à alteração entre viver ou saúde (haujë-) e morrer ou adoecer ( jưin-), estados e verbos que são concebidos como processos cíclicos associados às mudanças astronômicas, estacionais e à vida em geral (Langdon, 2014). Utilizando seu poder ou força (rau), os xamãs negociam com as entidades responsáveis por esses ciclos, o que inclui as figuras celestiais, tais como Sol, Lua e Trovão, o Povo yajé, bem como os donos e/ou pais e mães dos animais, plantas e zonas ambientais ou geográficas específicas. Para causar infortúnio e/ou doença com a produção e manipulação de rau, os xamãs também negociam com as entidades caracterizadas como perigosas, principalmente os huati.

Um etnógrafo capuchinho, Frey Plácido de Calella (1940-41), abre seu artigo publicado na revista Anthropos com três fotos: de curacas siona com seus cocares cerimoniais e colares de caninos de onça (Foto2: Curacas siona de Orito, (In: Apuntes sobre los indios siona del Putumayo. Anthropos 35-36: 737); de uma montagem de artefatos rituais incluindo o cipó de yajé, flautas, cálice e base para o recipiente de yajé; e dos desenhos de yajé pintados por um jovem siona. Calella observa que os curacas desempenham papel de sacerdote, mágico, médico e bruxo, e também que são chamados por vários termos: yai (onça), huati (fantasma ou Diabo), nãiké (ele que vê, vidente); dause-koké (ele que cura, médico) e uinhaké (ele que canta) (Calella, 1940-41: 743). Seu artigo contribui para o entendimento da tradução do canto de Castellví, porque o xamã canta (juin-) sobre os remédios para dotá-los com o poder de curar. A tradução mais adequada para dause-kokéé "ele que devolve" (rau gởigüe, na ortografia atual dos Siona). Calella também descreve aspectos da aprendizagem xamânica e indica que o segredo dos poderes xamânicos vem com a ingestão de yajé.

4 As transcrições neste trabalho utilizam a ortografia desenvolvida por Wheeler (1987) e adotada pelos Siona com algumas pequenas mudanças. 


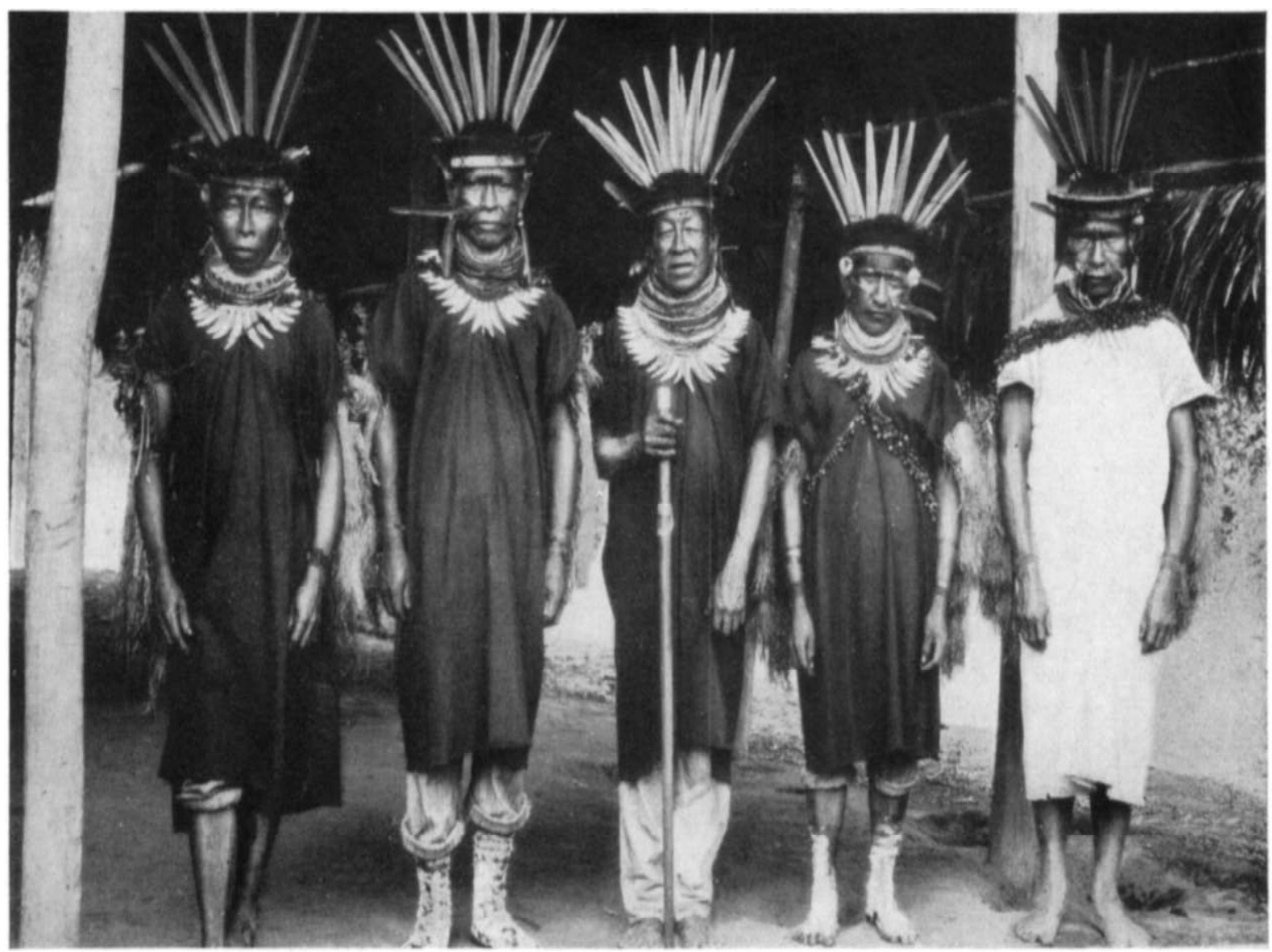

Foto 2: Curacas siona de Orito, (In: Apuntes sobre los indios siona del Putumayo. Anthropos 35-36: 737)

Antropólogos do Instituto Colombiano de Antropologia e História também tiveram muito interesse nas atividades dos curacas (Chaves, 1958). Carlos Garibello Aldana, responsável pela documentação de áudio e vídeo no Instituto, gravou cantos de yajé durante a década de 1950 e filmou ritos de cura (Langdon, 2013b). Dois artigos foram publicados, em meados dos 1960, descrevendo suas práticas xamânicas com base nas informações de Felinto Piaguaje, um jovem siona que trabalhou como informante para um linguista em Bogotá (Mallol de Recasens, 1963; Mallol de Recasens y Recasens 1964-5).

Enquanto os acadêmicos e outros estavam interessados em pesquisar e captar as performances xamânicas, os praticantes da tradição xamânica siona estavam desaparecendo no rio Putumayo. Durante os anos 1950 e início dos 1960, os últimos curacas poderosos morreram numa sequência de ataques de bruxaria. Inclusive, Rafael Paiyoguaje, cantor do texto citado antes, foi acusado de ser responsável por, pelo menos, três mortes de curacas, além do fim do último cacique curaca de Buena Vista. Quando os anciãos ainda vivos se juntaram para beber yajé e ver quem tinha rau suficiente para assumir o papel de liderança, o grupo todo sofreu de visões caóticas e escuras. Ou seja, ninguém se revelou poderoso suficiente, ninguém mais tinha rau suficiente para guiar os outros. Essa era uma época com muitas oportunidades novas que surgiam do contato intenso com não indígenas. Os jovens siona estavam ocupados em outras atividades e não mais se dedicavam à aprendizagem xamânica.

A década de 1960 marcou uma virada na configuração étnica no Putumayo. Durante a primeira metade do século XX, a imigração de colonos havia sido relativamente lenta por causa do isolamento 
da terras baixas e da falta de comunicações e estradas com a região andina. Porém, na década de 1950, descobriu-se petróleo perto da aldeia siona de San Diego e, em 1968, foi completada a estrada que conecta a região andina a Puerto Asis, um pequeno centro urbano ao redor da missão capuchinha e porto no rio Putumayo. Com essa estrada, milhares de colonos migraram para a região e se assentaram no entorno dos últimos territórios siona. Os Siona iniciaram o processo de integração na economia nacional e estavam abandonando sua língua materna e os modos tradicionais de vida, incluindo as práticas xamânicas.

Quando eu cheguei em Buena Vista, em 1970, a maior comunidade siona no rio Putumayo, quase todos eram bilíngues; suas roupas e arquitetura não mais os distinguia visualmente de seus vizinhos colonos. Não havia nenhum cacique curaca na comunidade e os anciãos não estavam realizando os ritos de yajé, apesar de que muitos deles haviam feito sua aprendizagem xamânica e participavam com grande prazer dos ritos realizados, em Buena Vista ou outros lugares, por xamãs que não eram Siona. Ainda assim, os Siona continuavam a procurar as causas de infortúnios e doenças segundo a visão de um universo perspectivista habitado por forças intencionais invisíveis. Ouvi lamentações constantes da perda de seu cacique curaca, que assegurava seu bem-estar por meio de negociações com as forças invisíveis e que os protegia de ataques dos huati que serviam aos xamãs mal intencionados.

Minha intenção inicial era pesquisar a relação entre as ideias sobre as causas das doenças e o itinerário terapêutico. Mas, rapidamente, tornou-se óbvio que as perguntas dos Siona sobre doenças eram de uma natureza bem diferente da das minhas. Ainda mais, ficou evidente a dificuldade de traduzir noções fundamentais sobre seu mundo xamânico. Assim, embarquei no trabalho de aprender a língua siona com os mais velhos. Solicitei a eles que me contassem histórias dos antigos, que gravei e depois transcrevi utilizando um dicionário e uma gramática de um linguista-missionário do Summer Institute of Linguistics. Após transcrever uma narrativa, retornava ao narrador para dialogar sobre meu entendimento. Essa metodologia provou ser mais que uma simples uma decodificação da linguagem, porque todas as narrativas tratavam da ontologia do mundo e das causas por trás dos eventos visíveis.

A partir das narrativas consegui compreender que o termo rau se aproxima bastante do conceito de mana e que seus significados ajudam a entender o exercício da agência num universo relacional. Para aprofundar o significado polissêmico de rau, vou apresentar trechos de várias narrativas que reproduzem as batalhas xamânicas do passado, bem como encontros pessoais e eventos no lado invisível. Esses trechos são exemplares no sentido de contextualizar os vários significados e usos de rau, o que possibilita aprofundar seu entendimento como uma noção tipo mana.

Rau, no seu sentido mais amplo, representa o poder de agência ou a força vital que circula entre humanos e não humanos, que se concentra em determinados seres (Langdon 1992: 47). Assim como o que Mauss (1974: 133) descreve por mana, o termo rau é de difícil tradução - escapa a nossos conceitos e lógicas. É uma qualidade, uma substância, um verbo, um substantivo e um estado que conotam um conceito abstrato de energia vital ou poder no universo, bem como uma substância encarnada que pode ser manipulada e trocada entre certos seres humanos e não humanos. Os xamãs, por meio da aprendizagem com yajé, acumulam rau nos seus corpos e desenvolvem uma capacidade para manipular seu rau conscientemente. Porém todos os humanos desenvolvem uma certa quantidade de rau no corpo à medida que 
envelhecem, e esse os protege dos ataques dos huati que não são motivados por xamãs. É a falta dessa força vital que torna os bebês e crianças vulneráveis aos ataques espontâneos. Da mesma maneira, certos seres não humanos que vivem nos domínios fractais do universo também possuem e manipulam esse poder, mas seria um erro presumir que todos os não humanos têm essa capacidade ou que essa energia é equivalente à noção de alma. Rau é uma força-poder que pode ser acumulada, possuída, manipulada, trocada e direcionada ou atirada. É a práxis xamânica. Todos os humanos, se possuem rau ou não, têm um coração ou alma (recoyo) como o centro do corpo e coragem, por isso podem ser atacados pelo buati. ${ }^{5}$

Quando um homem inicia sua aprendizagem xamânica e bebe o yajé regularmente, o rau cresce dentre dele enquanto está acumulando conhecimento sobre os mundos invisíveis. Rau como substância corporal representa seu conhecimento e poder obtidos nas experiências com yajé. O rau se acumula enquanto o aprendiz passa por uma sequência de viagens para diferentes reinos do universo, "chegando" e conhecendo os diferentes "povos" ou seus "donos" que residem lá (Langdon 2013a). Ele deve aprender a distinguir as características dos diversos povos nas viagens, os quais vêm cantando e se apresentando: "somos o Povo do yajê", "somos o Povo do Sol" etc. Para conhecer um povo ele precisa reconhecer sua maneira de viver, de vestir, além de aprender seus desenhos e cantos. O aprendiz continua tomando yajé e seu rau cresce de acordo com a progressão de seus conhecimentos sobre os seres e suas maneiras de viver no mundo fractal, no outro lado. Uma vez que acumula rau em quantidade suficiente, ele está capacitado a liderar os outros nos ritos de yajé.

Durante a aprendizagem, ele recebe objetos que possuem rau, na forma de pequenos cocos e sementes, flautas, ou outros, que os Povo do yajé (juinha bain), as alianças mais valorizadas, deixam cair. Os colares, cocares e outros adornos dos xamãs também possuem rau. Uma vez, conversando com Ricardo, um destacado narrador de experiências xamânicas, ele me mostrou um pequeno coco ou noz - escuro, duro e de formato apontado - que tinha recebido recentemente num rito, como evidência do conhecimento que estava acumulando ao tomar yajé com seu cunhado, um indígena Kofan. Suponho que ele incorporou esse objeto num colar ou outro adorno corporal. Em outra ocasião, presenteou-me com um dente canino de uma jaguatirica, dizendo que nunca deveria perdê-lo.

O processo de acúmulo de rau nunca termina. $\mathrm{O}$ desenvolvimento do conhecimento xamânico não é um processo limitado, pois sempre há outros domínios e outros não humanos a conhecer. Rau é a força por detrás da capacidade de transformar-se em onça, sucuri ou outros seres; é a força da cura e o que permite mediar com seres não humanos em diferentes níveis do mundo invisível. Rau também dota o xamã com a habilidade de trabalhar com estimulantes menos poderosos, tais como yoco (Paullinia yoco) ou bebidas alcoólicas. O rau pode ser ativado a partir do suor ou da ingestão de caiçuma ou aguardiente, ainda que a última tenha sido tradicionalmente proibida por seu potencial de danar o rau.

Porque o rau é uma substância corporificada, é necessário dispor adequadamente dos objetos do xamã após sua morte, ou eles continuam causando dano. Seus objetos precisam ser removidos de seu corpo e selados no oco de uma árvore na floresta. Seu cocar, colar de caninos de onça e outros implementos rituais - todos possuindo rau - devem ser destruídos. Os Siona me contavam que os colares de caninos de onça dos curacas eram particularmente perigosos. Durante a pesquisa, nos anos 1970,

5 Como observado para outros grupos amazônicos, os Siona representam o coração ou alma como pássaros. 
somente Ricardo se adornava com esse tipo de colar, era também o único, na época, que havia passado por uma aprendizagem xamânica extensa. No entanto, fiquei sabendo que a filha do irmão de Ricardo, o último cacique curaca reconhecido, guardou o colar de caninos de onça de seu pai após sua morte em vez de destruí-lo. Suas filhas me contavam de ruídos estranhos que ouviam à noite, na casa onde o colar estava guardado, e de algumas doenças da famíliaque foram atribuídas à presença do colar.

O rau está dispersado no corpo do xamã, mas também toma a forma concreta de dardos mágicos guardados em seu braço esquerdo, o qual "serve como uma porta-dardos". Nas batalhas xamânicas, o rau é mobilizado de várias de maneiras: ele é "trabalhado" ou "torcido" num projétil ou outro objeto para ser atirado no inimigo.

A seguir cito um trecho de uma narrativa relatando a batalha que aconteceu no local onde o rio Guepi desemboca no rio Putumayo. A citação trata da troca de rau. Dois grupos de caçadores de uma aldeia na boca do Guepi desapareceram na floresta. Num rito de yajé, o curaca viaja para a floresta para descobrir o que havia acontecido. Ele vê outro xamã, na forma de uma sucuri, comer seu povo. Então, ele monta um escudo de folhas de uma espécie de palmeira espinhosa, na beira do rio onde a sucuri está esperando com sua boca aberta. A referência a uma espécie de palmeira com espinhos, no texto, é um índice de rau e lembra a proteção de dardos (tsentsak) do xamã achuar-jivaro descrito por Michael Harner (1972) e Robert Crépeau (2007).

buabuaguëna, ëñaguëñ

Ele viu a sucuri flutuando.

're’oji, yureta'ã yëë rau yo'ozaniyë' ro'taguëñ.

'Ótimo, agora vou trabalhar meu rau' pensou. cani baguë rau ca'ëni, rau 'ëini, baguë 'aña pëkë raure baguëna baguëga. e pensando, torceu rau e atirou o rau, o rau da sucuri que possuía ba'iguëbi, hãã ca’ëni rau 'ëini 'aña pëkë yi’obona senjoni 'ayaguëña. Possuía, aquele rau, ele torceu e mandou para dentro da boca da sucuri. sejoni, 'ayaguëna, jâârëbi aña pëkë güina’ru baguë raure rauguëña. Mandou para dentro, e assim, de igual forma, a sucuri mandou seu rau. rauni baguëbi, tãäbana jããruna huen raquëña ba rau

Ele mandou, e no escudo mesmo o rau foi pego. buen raguëna, hãärëbi baguë beoru aña pëkë rausée rau chiaguëña. Foi pego, e assim o xamã recolheu o rau, todo o rau da sucuri. chiani, jãärëbi, te’e garabëna sinsoguëña.

Recolheu, e assim ele lapidou num pacote só. sinsoni jãârëbi baguë yacabuëna sejoni, ayaguëña.

Lapidou e assim o mandou para dentro do estômago.

sejoni, ayaguëna, jäảärëbi ba 'achoguëña.

Mandou para dentro e assim soou 'tuuuuh' achoguëñ.

'Tuuuuuuh' soou. 
achoguëna, 'reohi' rótaguëña.

soou, "Ótimo" o xamã pensou.

cani, añaya pëkëga jäâräbi caguëña, baguë cocabi.

Pensou, e então a sucuri falou em sua língua. 'mëë yёёre ro yóoguëni, yёёre rau yóohuë mёё 'caguëña. 'Você trabalhou contra a mim, para mim trabalhou seu rau' falou

Essa narrativa apresenta as várias maneiras de manipular ou possuir rau:

rau yo’ozayë - trabalharei rau é traduzido em espanhol para voy a brujear
rau cäën - torcer rau
rau chiaguëñ - recolher rau
rau ëini - atirar rau
raugüëña - rau como raiz verbal

As expressões do rau - como substância, verbo ou conhecimento - são centrais no drama da batalha xamânica e na troca desse poder entre os dois xamãs. A sucuri, provavelmente um xamã de uma outra aldeia, causou o desaparecimento dos caçadores na floresta. $\mathrm{O}$ xamã vingador pode ver o que estava acontecendo com seu povo através da toma de yajé. Na batalha que segue, os dois xamãs trocam rau na forma de projéteis. Quem ganha é quem retém o rau do outro, nesse caso, o vencedor tem o rau da sucuri em dois sentidos. O texto indica que ele já tem o conhecimento do Povo Sucuri e, além disso, ele retorna o rau que a sucuri atirou nele, lapidando-o num pacote (te’e garabë), traduzido pelo narrador como o bruxo da sucuri. Em nosso diálogo sobre a transcrição, Ricardo, o narrador, descreveu o rau da sucuri com aparência de cristais. A posse de rau é desigual entre seres humanos e não humanos, assim, nas batalhas, é necessário possuir o rau do oponente ou possuir mais rau que o outro.

Como já explicado, o posse de rau normalmente se dá por meio das viagens com yajé em que o xamã estabelece alianças com seres não humanos. Nos ritos, o mestre xamã guia o novato nas suas viagens para o outro lado, de modo que ele pode conhecer os diferentes povos, aprender onde cada um vive, seus costumes característicos, maneira de vestir, desenhos e língua. Essas trocas de poder também circulam em forma material. Xamãs frequentemente regressam de seus encontros no outro lado com plantas para curar, para fabricar adornos ou para outros fins.

Em outra narrativa (Langdon 1991), o xamã descobre que sua mulher está trocando comida por sexo com seu amante sucuri, que emerge vestido como um xamã de um poço de água na floresta, rodeado de chontillo, uma palmeira de importância medicinal. Porém, na narrativa anterior, a menção a chontillo indica seu uso para a produção de dardos. O marido traído fabrica uma "armadilha de pegar humanos" no caminho onde a sucuri passa. $\mathrm{O}$ cocar da sucuri se enrosca na armadilha e ele fica preso. Para barganhar sua liberdade, ele revela seu canto para o marido, que o libera naquele momento, mas, subsequentemente, ele usa essa força para vingar-se e matar a sucuri no poço onde se encontrava com a amante. 
O trecho a seguir é de uma terceira narrativa, que conta uma batalha xamânica acontecida numa aldeia do grupo oyo, localizado no rio Guepi abaixo. O xamã oyo está fabricando um recipiente de madeira para mandioca ralada, escavando um tronco com um facão quebrado. De repente, um outro xamã, que colocou a roupa de onça, ataca. O xamã oyo está trabalhando sem "pensar nada” e de repente a onça o ataca. Ele pula de um lado para outro, para se defender da onça. Seu facão quebrado se prova inútil e ele fica rouco de tanto cantar uma oração de defesa. Por sorte, seus esforços produzem suor, o que faz rau cair do céu, empoderando-o para se defender e ganhar a batalha.

yai yuara ainreguëna, jãäärëbi baguëbi ja’su ga’nihuë neguëña A onça estava pronta para comer, quando o corpo do Oyo começou suar neguëna, umubi baguëre rau joni tonguë ba'quëña.

Começou suar e do céu rau brotou e caiu Joni tonquëna, jäãrëbi baguë yai yảaguëna yai yỉobona rau garabëte senjoni ayaguëña. Brotou e caiu, então a onça bocejou e o outro mandou para dentro o pacote de rau na sua boca. sejoni, ayaguëna baguë cócoguëña Mandou para dentro e a onça engasgou co'coguë, caguëñ ai, mëë ro yóoguëna, mëë yëëre yo’ohuë jàyë caguëñ. Engasgando ela falou, 'oh, a mim está fazendo mal, a mim assim está fazendo, irmão maior' falou 'mёё ёa ba’jïi' caguëya 'Você pediu por isso' o Oyo falou. caguë, góquëna.

Falou e retornou para sua casa. gơni, baguë querë ñataguëna rau neguëña A onça retornou e já no próximo dia despertou com rau.

As mortes dos últimos curacas, nos anos 1950 e 1960, são relatadas em narrativas semelhantes. Foram aproximadamente sete xamãs, conduzindo ritos de yajé nas três aldeias vizinhas no rio Putumayo - Granada, Buena Vista e Pinuña Blanco. Suas mortes foram resultado de uma sequência de ataques que iniciaram com um sonho ruim de um curaca em Buena Vista. Nesse sonho, via que o curaca de Granada estava trabalhando seu rau contra ele, com a convicção de que tinha matado um de seus parentes. A morte de um curaca de Buena Vista, logo depois, iniciou uma sequência de retaliações entre os xamãs, até que o último cacique curaca de Buena Vista morreu, em 1961.

Um dos sobreviventes em Buena Vista lamentou sobre o fim dos curacas antigos:

Aqueles curacas, os que viam o Diabo, Andavam atirando rau e se mataram uns aos outros. Lutaram entre eles, mandando doenças até que todos terminaram.

Agora sofremos, Não tem animais para caçar; Não tem Sol. Perdidos terminaremos nossas vidas. 
Estamos sofrendo muito.

Agora não tem ninguém que tenha a capacidade de beber yajé e nos diga se vem o bem ou o mal. Tem um silêncio que ninguém pode penetrar. Somos pobres órfã̃s abandonados.

O único que podemos fazer é confiar que Deus nós protegerá até que morramos.

Se Deus nos ajudar, viveremos

Se Ele nos chamar, morreremos e descansaremos.

Em todas essas narrativas, rau é um poder corporificado e utilizado em contextos específicos, relacionados a ataques por não humanos ou xamãs. Rau é a força subjacente a infortúnios, desastres e também a êxitos na caça e na cura. Rau dota o xamã com a capacidade de agir para benefício ou malefício, com a identidade de bruxo, médico e sacerdote que o caracterizou nos tempos coloniais e persistiu até a década de 1970. Caciques curacas foram os protetores de suas aldeias e utilizaram o próprio rau em defesa de seu grupo. Esses mesmos xamãs foram acusados de atacar membros de outras aldeias. Apesar de alguns xamãs terem sido acusados de somente vestir a roupa do huati, o status de xamã, como possuidor de rau, implicava ambiguidade, dado que a fronteira entre bem e mal era relacional, não absoluta ou universal. $\mathrm{O}$ uso de rau com boas ou más intenções dependia de quem o mobilizava e também dos conflitos vigentes nas relações sociais. A etno-história dos Siona retrata os xamãs como a causa verdadeira das epidemias trazidas pelos caucheiros que destruíram várias de suas aldeias no início do século $\mathrm{XX}$. As mortes dos últimos curacas são ainda lembradas como consequência das rivalidades causadoras da grande batalha xamânica que colocou um fim aos ritos de yajé por quase 20 anos.

Além de todas as características apontadas antes, rau tem certa independência de quem o possui. Assim, emoções fortes, raiva ou até mesmo um pensamento ruim pode causar dano, ainda que a pessoa não o deseje conscientemente. Em meu primeiro período de pesquisa de campo, os Siona comentaram que era necessário ter cuidado nas relações com o curaca, para não provocar sua raiva, porque os pensamentos dele poderiam mobilizar o rau e causar dano, até mesmo sem que ele o quisesse no momento. Por outro lado, todos os adultos siona tem um pouco de rau e, igual aos xamãs, quando morrem, há sempre perigo de que causem doença ou morte entre os mais queridos ou seus inimigos. Em 1972, minha comadre contou que seu irmão estava sofrendo problemas de saúde por conta dos conflitos com sua mãe. Ele explicou que a mãe deles, como uma pessoa mais velha, também tinha rau e, provavelmente, seus pensamentos de ira foram a causa dos problemas de saúde do irmão.

Concluo, a partir de narrativas e afirmações como essa de minha comadre, que a tradução mais adequada para rau é "força vital". Rau é a força por trás dos ciclos de vida e morte no universo fractal. É melhor entendido como parte de um universo relacional e expressado num campo semântico que concerne aos ciclos processuais contínuos de vida e morte (Langdon 1992: 45) que se evidencia nos termos opostos: huaje - ser vivo, verde, jovem, gordinho ou forte, tenro, viver; ju'in - ser velho, mor- 
rendo, escuro, podre, emaciado. O processo cíclico, manifestado em todas as formas vivas e mudanças estacionais, é resultado das atividades dos não humanos nos diferentes domínios do universo fractal.

O bem-estar (buajë-) individual e coletivo era o objetivo dos ritos de yajé. Porém, na época que eu estava registrando narrativas de viagens xamânicas, os Siona esclareceram-me que yajé não é rau.yajé tem uma mãe que tem rau. Os donos dos animais tem rau, mas nem todos os animais o possuem. Os seres não humanos, no outro lado, assim como os seres humanos deste lado, são liderados por seus donos ou pais que têm mais rau. A ingestão de yajé era fundamental para que os xamãs acumulassem rau por conhecerem vários seres possuidores de rau e aprender seus desenhos e cantos. A distribuição de rau é desigual entre seres humanos e não humanos, de modo que as atividades xamânicas eram orientadas para captar, encarnar e mobilizar rau com fins de proteger e defender ou de vingar e atacar.

Além de força vital, o termo rau também era utilizado para indicar "doença". No caso das doenças causadas pelo envio de rau por parte de um xamã, huati ou outro ser não humano, rau designa especificamente a substância xamânica, na forma de um dardo ou objeto podre e escuro, dentro do doente, que deveria ser retirado por um xamã para que a pessoa se recuperasse.

Porém rau também podia significar um estado de doença genérico, estado em que a pessoa está impedida de realizar suas tarefas cotidianas, sem necessariamente indicar a intrusão de substância xamânica. Quando estavam se referindo a essa condição, independente de suspeitar da intrusão da substância rau, diziam que o doente "está morrendo" de um rau. Os processos da vida, seja a vida humana ou de outros seres ou plantas, abrangem um processo geral de nascer, crescer e entrar em declínio até o final, quando o morrer se completa. Estar com um rau como um estado de doença é expressado com o verbo "morrer" (ju’in-) e indica que a força vital da pessoa está em declínio. As atividades terapêuticas buscam reverter esse processo, retornando a pessoa ao "viver" (wajë-). No caso das doenças que não respondem às terapias usuais e conhecidas, ou nas que se prolongam, os familiares do doente começam a pensar no rau como uma substância presente que faz com que a doença não responda da maneira esperada aos tratamentos. Se é mera doença, sem envolver substância xamânica, rau indica uma condição temporária de declínio da força vital, a qual pode ser revertida com ervas ou outras terapias, quando a pessoa retorna ao estado de huajë- ou saúde. Na primeira pesquisa de campo, diziam que o xamã deveria cantar sobre todos os remédios a serem administrados a um doente, mas na prática isso só aconteceu com doenças que não respondiam rapidamente ao tratamento.

\section{Yajé e a revitalização xamânica: de multivocal para univocal}

Baseando-me em narrativas xamânicas e suas traduções, registradas na década de 1970, venho argumentando que o conceito de rau é um tipo mana, segundo o conceito clássico de mana discutido por Mauss (1974) e Lévi-Strauss (1974). A multivocalidade de rau presente nos trechos das narrativas selecionadas expressa ação, força, substância, qualidade ou estado. Pode significar amaldiçoar, mas também indica poder xamânico, força vital, memória e conhecimento. Como uma substância, encontra-se dispersa no corpo do xamã, mas também pode ser por ele recolhida, modelada, trabalhada e atirada como um objeto. Como qualidade, rau é associado à doença e morte, às cores escuras e ao apodreci- 
mento. Como estado, indica que alguém está doente ou morrendo, também algo podre ou mal. É um substantivo e também um verbo transitivo no campo semântico relativo aos processos de vida e morte. O xamã exercita seu rau para curar e negociar com os não humanos, para influenciar eventos, tais como o êxito na caça ou na pesca, para propiciar o bem-estar da coletividade. Porém, ele pode ativar seu rau no sentido de causar dano ou matar. Cada adulto acumula essa força vital enquanto envelhece. Rau, como aparece em suas várias formas gramaticais e contextuais, pode ser considerado expressão concreta da noção mais abstrata de poder, força ou agência xamânica. Em resumo, rau é uma noção tipo mana.

Entretanto, como fenômeno social, mana e rau têm trajetórias bastante divergentes nos diferentes contextos históricos e sociais. Estudos sobre usos e expressões contemporâneas de mana (Tomlinson e Tegan 2016) demonstram que esse termo não somente tem sobrevivido, mas também que tem adquirido proeminência global. Discursos sobre mana têm florescido nos campos políticos, religiosos e artísticos, ligados às políticas étnicas dos Maori e outros povos. A palavra aparece em novelas, discussões teóricas, performances culturais e jogos de computador. Mana tem sido apropriado pelas teologias da Nova Era como a força vital universal (Tomlinson e Tegan 2016: 14-15) e incorporado por ativistas e acadêmicos indígenas como uma orientação espiritual nos projetos de educação e reafirmação cultural (Thomlinson e Tegan 2016: 20-21).

Entre os Siona do Putumayo, rau, como conceito tipo mana, em seu significado de poder ou força mediadora no universo perspectivista, desapareceu quase totalmente. Porém, em seu lugar de força mediadora surgiram os novos xamãs siona, designados como taitas, e a planta Banisteriopsis ou yajé, como representações de identidade indígena nas políticas étnicas da Colômbia e nas práticas da Nova Era. Diferente de mana, o termo rau nunca se difundiu além dos grupos de língua tucano ocidental, apesar de haverem noções semelhantes por toda a Amazônia (Crépeau 2007). Missionários associaram rau com o mal, o bruxo e a doença, de modo que não utilizaram esse termo em traduções que procuravam palavras equivalentes para Deus e santos. Hoje, na interação dos Siona com as práticas globalizadas, a polissemia de rau desapareceu e foi reduzida à tradução unívoca de bruxo, objeto de feitiçaria ou bruxaria. Algumas de suas associações semânticas, porém, têm sido transferidas para planta do yajé. O yajé, mais conhecido por seu nome quéchua ayahuasca, destaca-se globalmente como uma planta sagrada que medeia as relações com o mundo não humano e dos povos indígenas com não indígenas (Labate and Goulart 2005; Labate and Cavnar 2014).

Como uma das substâncias mais importantes, atualmente, nas práticas neo-xamânicas globalizadas que usam as plantas sagradas como transmissores do conhecimento primordial para a salvação do planeta (McKenna 2005), a ayahuasca circula nas performances rituais, que estão emergindo em novas formas, entre os grupos indígenas e não indígenas (Caicedo-Fernandez, 2015; Langdon, 2013c). $\mathrm{Na}$ Colômbia, o yajé foi incorporado às práticas mestiças de curandeirismo no período colonial e o xamanismo indígena é considerado a base da medicina popular contemporânea (Pinzón e Garay 1997; Taussig 1987). Grupos que procuram ritos de yajé se expandiram nas décadas de 1980 e 1990, e os profissionais urbanos começaram a participar nos ritos como parte de sua busca por cura individual e experiências espirituais (Caicedo-Fernandez 2009). Os xamãs da floresta, antigamente conhecidos como curacas e agora chamados taitas, circulam hoje nos centros urbanos para realizar as tomas de yajé 
para uma diversidade de pessoas. A associação do yajé e do xamanismo ao conhecimento primordial para a defesa da natureza manifesta-se em movimentos de identidade, medicina tradicional, performances culturais, produções estéticas contemporâneas e encontros espirituais (UMIYAC 1999; Ulloa 2005). Interesses e imaginários diversos permeiam eventos culturais, políticos e estéticos, promovendo a diversidade cultural, o conhecimento ancestral e a medicina tradicional (Foto3: Poster do Encontro Internacional das Culturas Andinas, 2014).

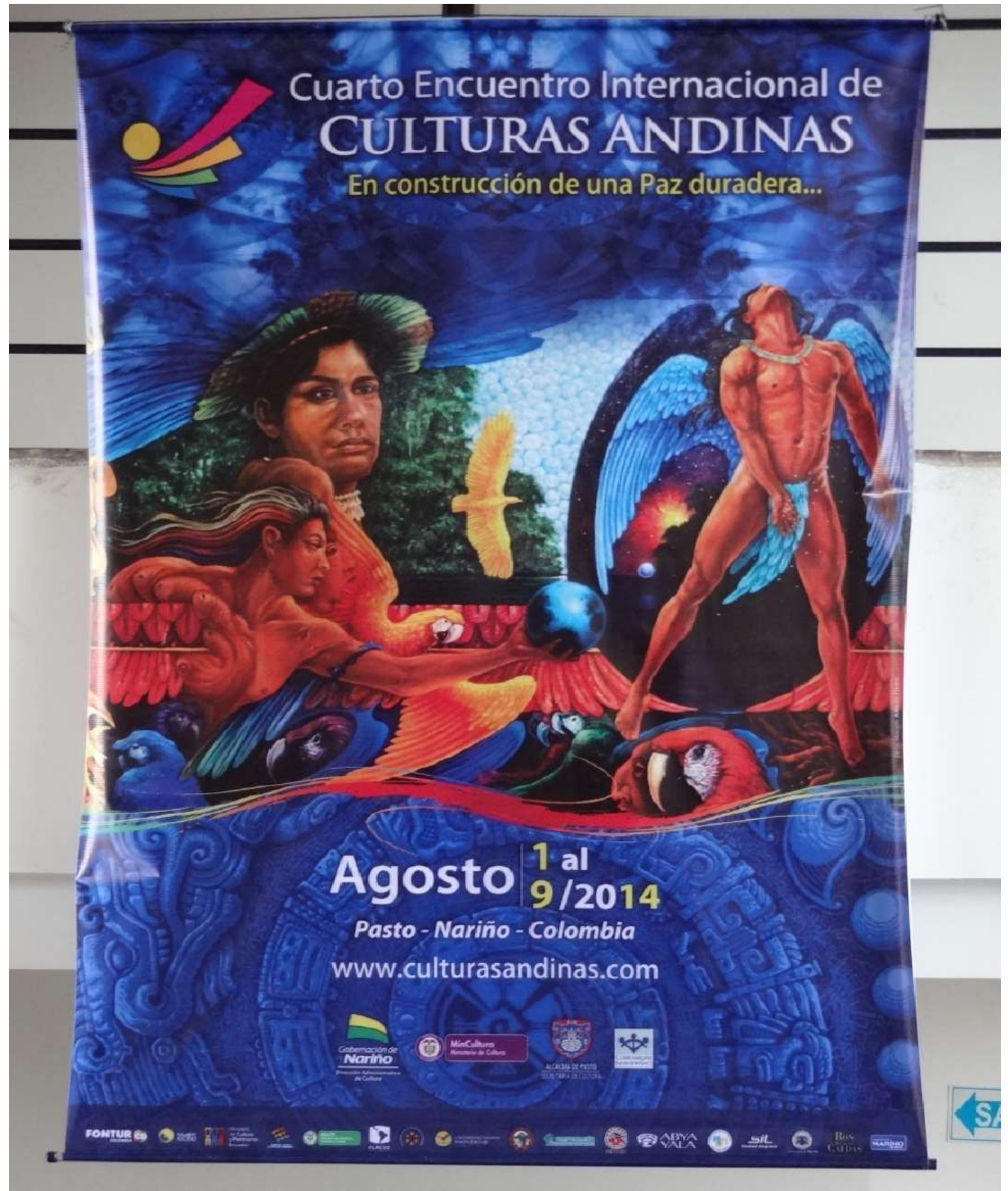

Foto 3: Poster do Encontro Internacional das Culturas Andinas, 2014 
Uma extraordinária revitalização do xamanismo siona tem acontecido como consequência das mudanças no status político e social dos povos indígenas desde a Constituição de 1991, bem como da demanda neo-xamânica pelas tomas de yajé (Langdon 2016a, b; Musalem 2016). A situação que existia nos anos 1970, de ausência de ritos realizados pelos curacas siona, reverteu-se totalmente. Os rituais liderados pelos taitas siona foram ressuscitados e reelaborados por meio do diálogo com uma rede que liga os grupos étnicos, no Putumayo, com o movimento indígena nacional e o movimento neo-xamânico das cidades andinas. (Foto5 Homenagem ao Taita Pacho, pintura numa parede em Puerto Asis, Foto de Pedro Musalem) Os taitas siona transportam suas preparações de yajé e realizam tomas de yajé para os buscadores de experiências espirituais e, também, com apoio de uma ONG internacional, conduzem "brigadas de medicina” em que difundem os ritos de yajé entre as comunidades indígenas que o abandonaram ou que nunca usaram.

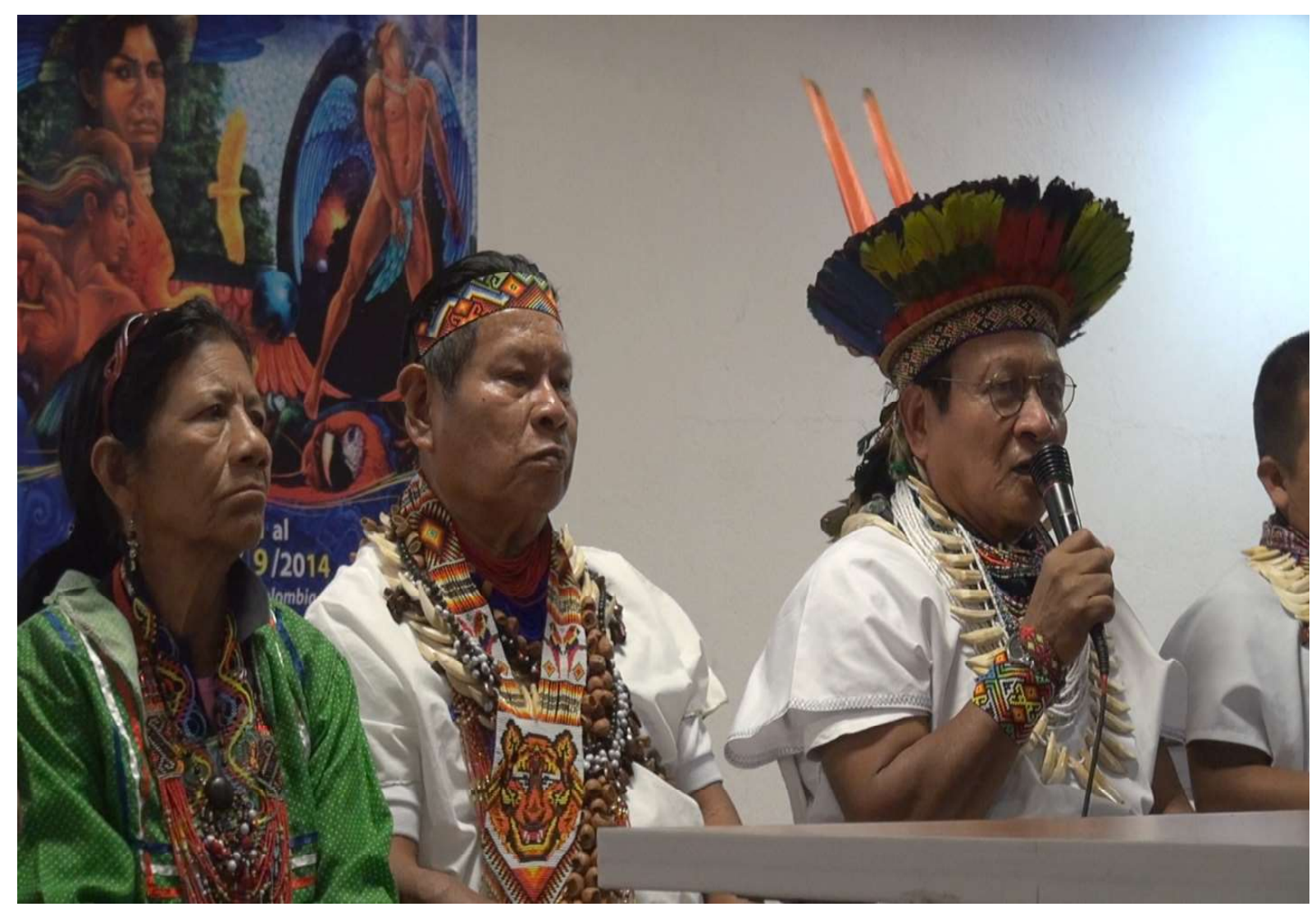

Foto 4: Os taitas siona falam do yajé no Encontro Internacional das Culturas Andinas, 2014

Certas características que constituíam o xamanismo siona se reconfiguraram. A estrutura e o conteúdo simbólico dos rituais estão se tornando mais homogêneos e assemelhados aos da rede maior. Elementos de catolicismo popular, na forma de preces e objetos rituais, aparecem mais. Novos instrumentos musicais, ritmos e cantos foram incorporados e são bem mais variados comparados àqueles registrados na primeira metade do século XX por missionários e antropólogos. A roupa e os adornos corporais já incluem os motivos e objetos que representam a indigeneidade global (Graham e Penny, 2014; Conklin 1997).

Um impacto importante que resulta da participação dos Siona na rede de neo-xamanismos globais é a mudança na imagem do xamã (Foto4 Os taitas siona falam do yajé no Encontro Internacional 
das Culturas Andinas, 2014). No passado, o xamã era uma figura ambígua por possuir rau, já que era capaz de exercer seu poder para causar malefício tanto quanto benefício. O universo relacional de trocas entre humanos e não humanos não era um universo amoroso, mas um universo intencional em que processos de saúde e bem-estar eram negociados. O discurso público contemporâneo sobre a ambiguidade da agência xamânica mudou. Os taitas siona afirmam que não se transformam mais em onça ou sucuri. ${ }^{6}$ Em 2013, um taita me disse, como membro da União de Médicos Indígenas Yajeceros de Colômbia, que apoia as viagens e brigadas médicas, que eles não fazem mais feitiçaria. Difundem os ritos para divulgar o conhecimento ancestral e para a proteção do ambiente. Entre os grupos urbanos, os taitas são reconhecidos como sábios benévolos que os guiam, nas tomas de yajé, na procura de autoconhecimento, cura e espiritualidade (Caicedo Fernández 2009).

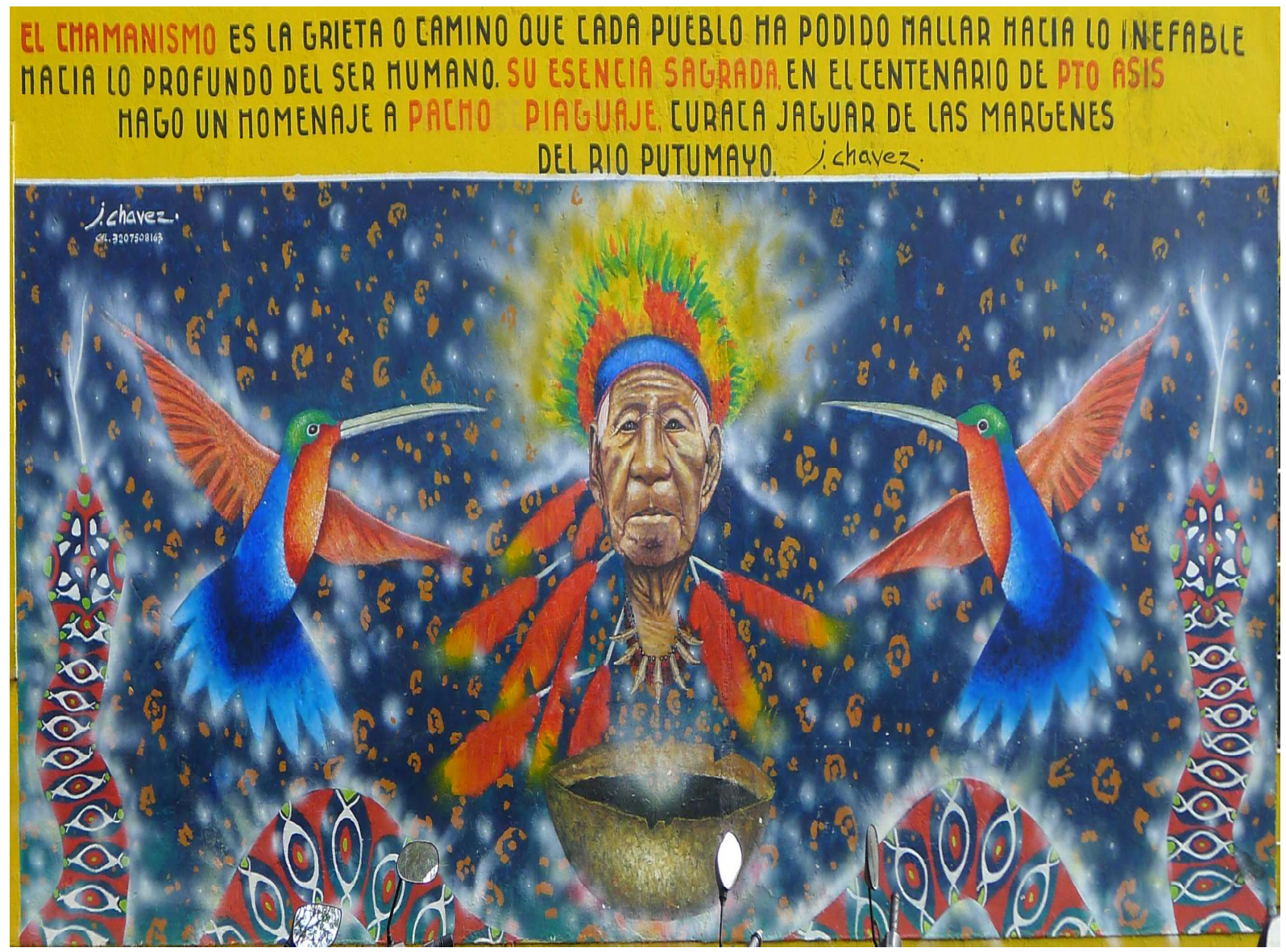

Foto 5: Homenagem a Pacho Puerto Asís, 2014

Simultaneamente aos processos históricos que resultaram na revitalização dos ritos, o conceito de rau como um fenômeno social está desaparecendo dos discursos xamânicos e seu significado está reduzido. Com a perda da língua siona e em diálogo com o movimento neo-xamânico, em que se valoriza a planta Banisteriopsis como a força maior de mediação e conhecimento, rau não mais expressa agência ou força espiritual num universo cíclico. Suas referências polissêmicas foram reduzidas ao sig-

6 Em correspondência pessoal, Pedro Musalem observou que hoje os colares dos dentes de onça são guardados e utilizados como representações da "cultura tradicional". 
nificado unívoco de bruxo, a substância de bruxaria. O conceito rau está sendo substituído pelo yajé como a planta sagrada que transmite conhecimentos e que medeia as relações entre seres humanos e não humanos. A ênfase é posta no yajé como o elemento essencial para experimentar o contato com a alteridade. O yagé, como planta sagrada, é a fonte de conhecimento e agência no universo animista da ontologia da Nova Era.

Esther Jean Langdon éprofessora da Universidade Federal de Santa Catarina, pesquisadora do CNPq e do Instituto Nacional de Ciência e Tecnologia - Brasil Plural 


\section{REFERÊNCIAS BIBLIOGRÁFICAS}

CAICEDO-FERNÁNDEZ A. 2009. Nuevo chamanismos nueva era. Universitas Humanistica, 68: 15-32. 2015. La Alteridad Radical que Cura. Bogotá: Universidad de los Andes.

CALELLA, PM de. 1940-41. Apuntes sobre los indios siona del Putumayo. Anthropos 35-36: 737-749. CASTELLVÍ, P. M. de. 1944-5. Mitología y dialectos sionas. 'Wixá Koxká. Unpublished manuscript. Bogotá: Arquives of Centro de Investigación Linguistica e Etnográfica de la Amazonía Colombiana in Bogotá-CILEAC.

CHAVES, M. 1958. Mítica de los siona del alto Putumayo. In: Santiago Geovés (ed) Miscelánea Paul Rivet octogenaria dicat, 2. Mexico, Universidad Nacional Autónoma de México, 121-150.

CIPOLLETTI, M.S. 1999. Dos escritos inéditos del jesuíta Pablo Maroni sobre el Noroeste amazónico (indígenas Encabellados, Tucano, 1739-40). Jahrbuch für die Geschichte Lateinamerikas 36 (1): 151-171.

2011. Hacia un shamanismo 'light'? Cambios e adaptaciones en procesos religiosos en la Amazonía peruano-ecuatoriana (siglos 18 al 21). Anthropos 106: 463-473.

CONKLIN, Beth. 1997. Body Paint, feathers, and videos: Aesthetics and Authenticity in Amazonian Activism. American Ethnologist 24(4):711-737

COSTA, L. e FAUSTO, C. 2010. The Return of the Animists: Recent Studies of Amazonian Ontologies. Religion and Society: Advances in Research 1: 89-109.

CRÉPEAU, R. 2007. Les substances du chamanisme. Perspectives sud-amérindiennes. Anthropologie et Sociétés 31(3): 107-125.

CRÉPEAU, R. e LAUGRAND, F. 2017. Introduction. Flux et fluids ontologiques: Repenser les notions de type mana. Social Compass 64(3): 313-327.

GÓMEZ LÓPEZ, A J. 2006. Fragmentos para una historia de los Siona y de los Tukano Ocidentales. Revista Inversa 1(2): 80-107.

GRAHAM, LR e PENNY HG (eds). 2014. Performing Indigeneity: Global Histories and Contemporary Experiences. Lincoln: University of Nebraska Press.

HARNER, M. 1972. The Jivaro: People of the Sacred Waterfall. New York, Doubleday.

KOLSHUS, T. 2013. Codrington, Keesing, and Central Melanesian mana: Two Historic Trajectories of Polynesian Cultural Dissemination. Oceania 83(3): 316-327.

LABATE, B. e GOULART, S. (eds). 2005. O Uso Ritual das Plantas de Poder. Campinas, Mercado de Letras/FAPESP.

LABATE, B. e CAVNAR, C. (eds). 2014. Ayahuasca Shamanism and Beyond. New York: Oxford Ritual Studies.

LANGDON, E. J. 1991. When the Tapir is an Anaconda: Women and Power Among the Siona. Latin American Indian Literatures Journal 7(1): 7-19. 
1992. Dau: Shamanic Power in Siona Religion and Medicine. In: Langdon EJM and Baer G (eds) Portals of Power: Shamanism in South America. New México: University of New Mexico Press, pp. 41-62.

.2013a. 'La visita a la casa de los tigres': La contextualización en narrativas sobre experiencias extraordinarias. Revista Colombiana de Antropologia 49(1): 129-152.

2013b. Perspectiva Xamânica: relações entre rito, narrativa e arte gráfica. In: Severi, C. and Lagrou, E. (eds). Quimeras e diálogo: xamanismo, grafismo e figuração. Rio de Janeiro: 7 Letras, 111-137.

2013c. New Perspectives of Shamanism in Brazil: Shamanisms and Neo-Shamanisms as Dialogical Categories. Civilizations: Revue internationale d'anthropologie et de sciences humaines 61(2): 19-35.

2014. La negociación de lo oculto: chamanismo, medicina y familia entre los Siona del bajo

Putumayo. Popayán, Colombia: Editora Universidade del Cauca.

.2016a. The Revitalization of yajé Shamanism among the Siona: Strategies of Survival in Historical Context. Anthropology of Consciousness 27(2): 180-203.

.2016b. The Performance of Diversity: Shamanism as a performative mode. GIS Gesture, Image and Sound - Journal of Anthropology. 1(1):9-39.

http://www.revistas.usp.br/gis/article/view/116460/114057

. (no prelo). refácio, In Labate, BC.; Goulart, SL. (orgs). O Uso de Plantas Psicoativas nas Américas. Terceiro Nome, Gramma, NEIP. Rio de Janeiro.

LÉVI-STRAUSS, C. 1974. Introdução à obra de Marcel Mauss. In Sociologia e Antropologia Vol 1. São Paulo: Editora Pedagógica e Universitária Ltda/Editora da Universidade de São Paulo. pp. 1-35. MALLOL DE RECASENS, M. R. 1963. Cuatro representaciones de las imagenes alucinatorias originadas por la toma del yagé. Revista Colombiana de Folclor III (8): 59-79.

MALLOL DE RECASENS, M. R. e RECASENS T. J. 1964-65. Contribución al conocimiento del cacique-curaca entre los Siona. Revista Colombiana de Antropologia 13:91-145

MCKENNA, D. J. 2005. Ayahuasca and human destiny. Journal of Psychoactive Drugs 37, 231-234. MAUSS, M. 1974. Esboço de uma teoria geral da magia. In Sociologia e Antropologia Vol 1. São Paulo: Editora Pedagógica e Universitária Ltda/Editora da Univerisade de São Paulo. pp. 37-206.

MUSALEM NAZAR, P. C. 2016. Xamanismo, memoria e identidade: transformações e continuidades nos processos politicos dos Siona do Putumayo, Colômbia. Florianópolis, PPGAS/UFSC: Ph.D. Thesis in Anthropology.

ORTIZ, S. E. 1942. Vocabulario de la lengua que usan los indios destas misiones - Ceona. Revista de Historia 1(2): 137-204.

PINZÓN, C. E. e GARAY, G. 1997. Las nuevas construcciones simbólicas en América Latina. Entre lo local y lo global. Bogotá, Equipo de Cultura y Salud - ECSA. 
SEEGER, A., DA MATTA, R e VIVEIROS DE CASTRO, E. 1987 A construção da pessoa nas sociedades indígenas brasileiras. In: Oliveira Filho, JP de (ed) Sociedades Indigenas e Indigenismo no Brasil. Rio de Janeiro: UFRJ/Editora Marco Zero. pp.11-30.

TAUSSIG, M. 1987. Shamanism, Colonialism, and the Wild Man: A Study in Terror and Healing. Chicago: University of Chicago Press.

TOMLINSON, M. e TENGAN, T. P. K. 2016. New Mana: Transformations of a Classic Concept in Pacific Languages and Cultures. Australia: The Australian National University Press.

ULLOA, A. 2005. The Ecological Native. Indigenous People's Movements and Eco-Governmentality in Colombia. London-New York: Routledge

UMIYAC - Unión de Medicos Indígenas Yageceros de Colômbia. 1999. Encuentro de Taitas en la Amazonía Colombiana. Santafé de Bogotá, Colômbia: UMIYAC.

VIVEIROS DE CASTRO, E. B. 1998. Cosmological Deixis and Amerindian Perspectivism. Journal of the Royal Anthropological Institute 4: 469-488. 2004. Perspectival Anthropology and the Method of Controlled Equivocation. Tipiti 2(1): 3-22. .2006. A floresta de cristal: notas sobre a ontologia dos espíritos amazônicos, Cadernos de Campo 14/15:319-338.

WASSERSTROM, R. 2017. 'Yo fuí vendido' Reconsidering Peonage and Genocide in Western Amazonia. Advances in Anthropology 7:35-54.

WHEELER, A. 1987. Gantëya bain (El pueblo siona del rio Putumayo, Colombia). Bogotá: Instituto Lingüístico de Verano. 2 vols 


\title{
MANA E SUBSTÂNCIAS XAMÂNICAS: AS RECONFIGURAÇÕES DE PODER ENTRE OS SIONA DA COLÔMBIA
}

Resumo: Inspirada pela discussão recente de Crépeau e Laugrand sobre mana, examino, entre os indígenas siona, a noção de rau como o conceito central para entender spoder xamânico e práticas rituais. Assim, em vez de tratar rau como uma categoria estável do pensamento e de práticas indígenas, exploro essa noção como um conceito fluido e polissêmico que tem sofrido transformações no decorrer de contextos históricos e sociais. Como as discussões recentes sobre mana demonstram, rau é melhor entendido como um fenômeno social cujos usos e significados têm se transfigurado através do tempo e espaço. Rau foi primeiramente notado e traduzido por missionários no século XVII. Minha análise baseia-se em traduções do termo rau encontradas em documentos de missionários franciscanos e capuchinhos, nas traduções dos Siona oferecidas a mim na década de 1970, em diálogo sobre suas narrativas xamânicas, como também em traduções mais recentes oferecidas pelos taitas siona, num contexto de revitalização xamânica iniciado na década de 1990.

Palavras-chave: xamanismo, poder, Siona, mana, tradução

\section{MANA AND SHAMANIC SUBSTANCES: THE RECONFIGURATIONS OF POWER AMONG THE SIONA OF COLOMBIA}

\begin{abstract}
Inspired by the recent discussion of Crépeau and Laugrand on mana, I examine the notion of rau among the Siona indigenous people. It is a concept central for the understanding of shamanic power and ritual practices. Rather than treating rau as a stable category of thought and ritual practice, I explore this notion as a fluid and polysemic concept that has undergone transformations throughout different historical and social contexts. As the recent discussions on mana demonstrate, rau is best understood as a social phenomenon whose uses and meanings have transfigured across time and space. Rau was originally reported and translated by missionaries of the XVII Century. My analysis is based on translations of the term rau found in Franciscan and Capuchin missionary documents and on translations offered to me during the decade of 1970 in dialogue with their shamanic narratives, as well as on more recent translations offered by Siona taitas in a context of shamanic revitalization initiated in the decade of 1990.
\end{abstract}

Keywords: shamanism, power, Siona, mana, translation

RECEBIDO: $20 / 06 / 2018$

APROVADO: $23 / 06 / 2018$ 